\title{
Changes in the geographical distribution of religious heterogeneity in Czechia during the transformation period
}

\author{
TOMÁŠ HAVLÍČEK, MARTINA HUPKOVÁ, KAMILA SMRŽOVÁ \\ Charles University in Prague, Faculty of Science, \\ Department of Social Geography and Regional Development
}

\begin{abstract}
The paper has attempted to generalize changes in the geographic distribution of religious heterogeneity or homogeneity in Czechia during the transformation period from 1991 to 2001. Areas with a higher degree of religious homogeneity exhibit smaller declines in the level of homogeneity when compared with regions with a higher level of religious heterogeneity, which also exhibit greater declines in homogeneity or greater increases in spatial religious heterogeneity. In this way, the regional differentiation of Czechia's religious landscape is becoming more pronounced.
\end{abstract}

Key words: geography of religion - spatial distribution - Czechia - religious heterogeneity and homogeneity

\section{Introduction}

According to the portion of its residents, claiming religious beliefs, Czechia ranks as one of the most secularized countries in the world. Park (1994) conceives secularization primarily in three ways: a) the elimination of religious faith (increasing separation of church and state), b) the unimportance or rejection of religious ideas (a decline in interest in religious traditions as well as in the familiarity with and respect for church representatives) and c) the process of thoughts and actions becoming more worldly leading to the ultimate end of interest in religious ideas. Secularization is a long-term and continuing trend in Czech society. However, as Hamplová (2000) states, "it is necessary to distinguish between traditional religion and faith in supernatural forces in general."

Secularization theory occupies an important position in geographic research of religion, especially in explaining religious-geographic dependencies within modern-day Europe (e.g. Henkel, Knippenberg 2005, Wunder 2005).

Czechia, with its position in central Europe, is influenced by European secularization trends (Knippenberg 2005), and, of course, as an open country, it is also in- 
fluenced by the continuously spreading forces of globalization and internationalization. Results from the Population and Housing Census (hereinafter only the census) in 1991 and 2001, subsequent to 1989, show a decrease in residents, who claim membership to a church or religious society. However, at the same time, the religious scene in Czechia, after 1989, is becoming increasingly differentiated. Large churches such as the Roman Catholic Church, protestant churches and the Czechoslovak Hussite Church are losing adherents along with their influence, while small, newer churches are experiencing completely the opposite, in terms of development, wherein numbers of adherents to these churches are increasing. These progressively developing churches include smaller Christian societies (Brethren Evangelical Free Church, Adventists, Evangelical Free Church), Jehovah's Witnesses, the Orthodox Church (due to the immigration of Russians and Ukrainians) and others. The joint share of adherents to these progressive churches and religious societies only amounts to a few single percentage points and their influence in the ultimate outcome of changes between 1991 and 2001 is not so great. In spite of the decline mentioned, in terms of individuals declaring their religious affiliation between 1991 and 2001, it is still possible to find areas, where people are claiming membership in certain denominations at increasing rates. This article shall also explore the issue of establishing a database that is appropriate for spatial analyses of believers in Czechia.

How were the adherents to various religious communities in Czechia regionally distributed at the beginning of the $21^{\text {st }}$ century? To what degree are these distributions similar to those from 1991? Are there areas in Czechia, which stand out with significant changes in the number of adherents to various, individual churches? Can we find areas, which are stable, wherein neither a loss of adherents to traditionally "strong" churches is evident nor is there significant growth in the number of adherents to new religious societies?

A key assumption in the presented research is the idea of increasing religious heterogeneity as a factor, which can subsequently contribute to the mitigation or even termination of secularization processes in these religiously heterogeneous areas. On the other hand, territories with a greater level of religious homogeneity should also exhibit a higher degree of secularization.

\section{Developments previous to 1991}

In 1991, a significant decline in the number of adherents to all of main, monitored churches (see table 1) became evident from the census. For the Roman Catholic Church, a relative decline of nearly one half from $76.4 \%$ (in 1950) to $39 \%$ (1991) was recorded. Evangelical churches saw an even greater decrease in the number of adherents. In contrast, marginal religious societies (Jews, evangelical churches) witnessed relative stagnation in terms of numbers of adherents, during the Communist period. While the decline in adherents to large churches (the Ro- 


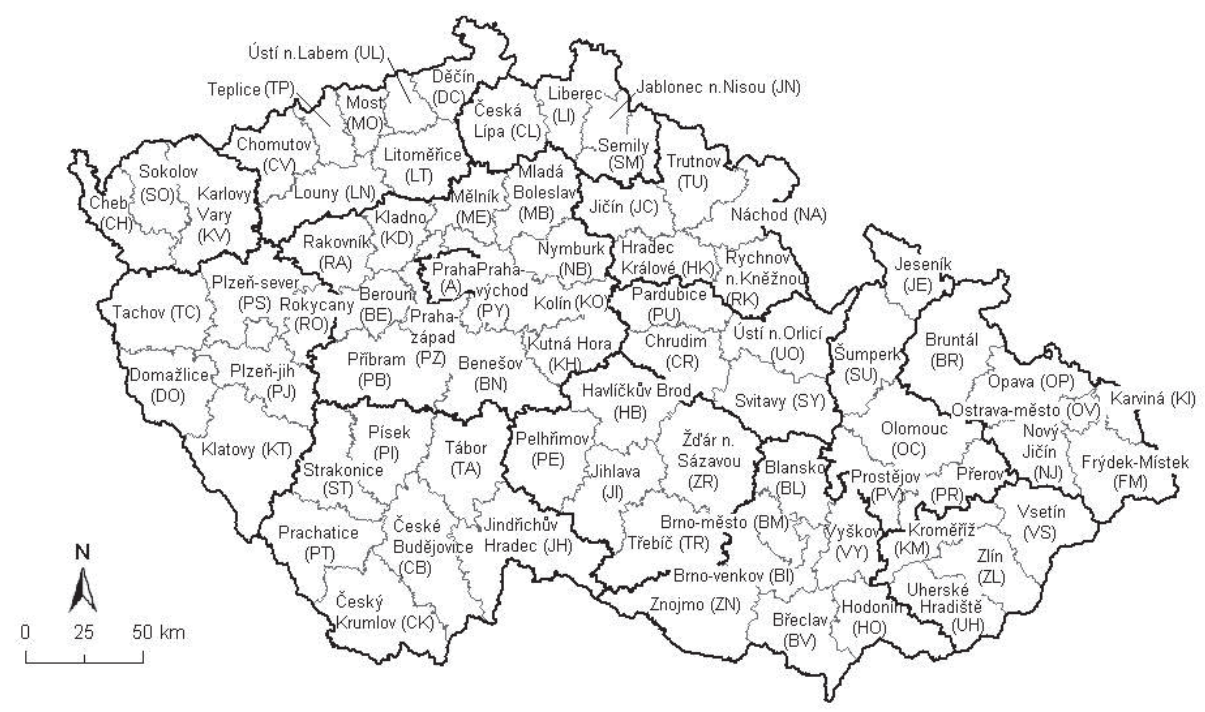

Fig. 1 Districts of Czechia

Source: authors' creation.

man Catholic Church, Czech Brethren Church and Czechoslovak Hussite Church) continued after 1989, smaller churches began to grow (Havlíček 2005).

The number of residents, who refused to answer the question on faith was also relatively large - in contrast with the previous census of religiosity. This portion increased from $0.3 \%$ (1950) to $16.2 \%$ (1991). Subsequent to the fall of the communist regime in 1989, this portion fell below $10 \%$ (2001).

Tab. 1 Breakdown of religious denominations in Czechia in 1921, 1930, 1950, 1991 and 2001 (\%)

\begin{tabular}{|l|r|r|r|r|r|}
\hline Categories & $\mathbf{1 9 2 1}$ & $\mathbf{1 9 3 0}$ & $\mathbf{1 9 5 0}$ & $\mathbf{1 9 9 1}$ & $\mathbf{2 0 0 1}$ \\
\hline Roman Catholics & 82 & 78.5 & 76.4 & 39 & 26.7 \\
\hline Greek Catholics & 0.1 & 0.1 & 0.4 & 0.1 & 0.1 \\
\hline Evangelic (total) & 4 & 4.7 & 5.7 & 2.5 & 1.5 \\
\hline Evangelic Church of Czech Brethren & 0 & 2.7 & 4.5 & 2 & 1.1 \\
\hline Orthodox & 0.1 & 0.2 & 0.6 & 0.2 & 0.2 \\
\hline Czechoslovak Hussite Church & 5.2 & 7.3 & 10.6 & 1.7 & 1 \\
\hline Judaism & 1.3 & 1.1 & 0.1 & 0.1 & 0.1 \\
\hline other (Brethren, Baptists etc.) & 0.1 & 0.1 & 0.1 & 0.1 & 0.8 \\
\hline non-denominationalists & 7.2 & 7.8 & 5.8 & 39.9 & 58.2 \\
\hline no data & 0 & 0 & 0.3 & 16.2 & 10.3 \\
\hline
\end{tabular}

Source of data: Czech Statistical Office (CZSO) 2008.

During the period of the communist dictatorship, considerable persecution of religious societies, churches and monastic orders took place. Over time, all monas- 
teries and convents were closed and a period of communist propaganda with the objective of secularizing Czech society began. Even though at least a partial renewal of interest in Christian values occurred after the Second Vatican Council (Daněk, Štěpánek 1992), the portion of residents claiming no denomination had grown enormously by the beginning of the 1990s. This growth was from slightly less than 6\% (1950) to nearly 40\% (1991). Greater growth was recorded in Bohemia (46.1\% non-denominationalist) than in Moravia and Silesia, where this share was not quite $30 \%$.

According to Lužný and Navrátilová (2001), three primary factors, which contributed to secularization trends in Czech society, include:

1) Anti-Catholic sentiments of the Czech society in general (from Hussitism to national revival and resistance to the Hapsburg Empire to communist atheism).

2) Secularization tendencies arising from the structural differentiation of modern society.

3) Atheist propaganda from the communist regime.

\section{A discussion of the database}

This analysis is based on data concerning population, as recorded in censuses for 1991 and 2001, which form the only appropriate source of comprehensive information for spatial analyses regarding religious denominations. A frequently referenced disadvantage of these data, which disclose information on the portion of adherents to various religious societies in a given territorial unit, is that they are only capable of describing the membership of residents to a given religious society (Sobotka, Adigüzel 2002). Our analysis, however, only concerns the portion of believers, who have declared their membership in a certain religious society and not believers as a whole, which should also include believers, who do not feel that they belong to any specific church.

Neither in the 2001 nor the 1991 census was there a category to clearly describe this group of the Czech population. Lužný and Navrátilová (2001), who base their conclusions on the results of the European Values System studies conducted in 1991 and 1999, demonstrate the fact that categories of general believers and of individuals claiming membership in certain religious groups will not necessarily have identical coverage. They show that roughly $70 \%$ of people, who consider themselves to be believers, also claim membership in a denomination of some sort, meaning that the remaining $30 \%$ of believers exhibit an undefined type of religiosity. The decline in individuals, who do not claim membership in any religious society, between 1991 and 2001 (from $85 \%$ to the $71 \%$ mentioned), indicates that this increasing deinstitutionalization of religiosity is indeed happening.

Hamplová (2000) also notes that the portion-of-believers indicator is not appropriate for expressing the nature of the religious faith of Czechia's inhabitants, be- 
cause some believers claim membership in a religion as a historical or cultural tradition and by no means due to the fact that they uphold or adhere to its religious dogma. Z. R. Nešpor has also weighed in concerning the distinction between the terms "believer" and "atheist". He claims some people refer to themselves as being "without religion", when in reality they are merely trying to emphasize that they do not belong to any particular church (Nešpor 2004).

In the upcoming 2011 census, efforts will be taken to avoid these mentioned conflicts in religious statistics. From public discussion on the proposal for the legal act on this census it appears that the question concerning religion will no longer be conceived merely as the ascertainment of a person's membership in a particular denomination, but that its formulation will be more generally directed at "religious faith" (CZSO 2008).

In our case, therefore, on the basis of the above information, the fact that religious denomination was not, due to the voluntary nature of responses to this question, ascertained for all residents of Czechia partially lowers the declarative power of the data. In 1991, the group of people with an unascertained religious denomination comprised $16.2 \%$, and in $20018.8 \%$, of the entire population of Czechia. Another pitfall of these data is the fact that by merely filling in the name of a church or religious society (see the censuses from 1991 and 2001), to which an individual claims membership, it is impossible to ascertain the strength of the relationship of any given individual to their declared church or religious society. The number of believing residents obtained in this manner, therefore, includes a large amount of such relationships, ranging from passive membership, wherein an individual merely declares his/her relation to a given church or religious society, but is not actively involved in religious life of the community, to highly active membership, in which believers participate in all of the activities and events organized by the church or religious society. In spite of the indicated shortcomings, it is necessary to a reaffirm the fact that data regarding religious denomination from the 1991 and 2001 censuses is the only high-quality and accessible source of information that is regionally organised, even to the municipality level. In this article, regional variability is examined at the district level. The term believing residents in this article shall describe all residents, who declared their membership in any religious society in the census.

\section{The regional distribution of religious heterogeneity}

\section{The structure of religious denominations}

According to the most recent information (Ministry of Culture of the Czech Republic, September 2009), there are 31 churches and religious societies registered in Czechia. Recent additions to this registry include, for example, the New Hope Church (registration 3. 9. 2009) and the Church of the Living God (registration 
15. 12. 2007). During the post-communist period, a total of 13 entities have become newly registered. While their membership rates are relatively low, generally in the thousands, or in some cases in the tens of thousands, of individuals, they are evidence of the fact that Czech society is not "doomed" to decline into a nearly absolute profane society, but that, in contrast, smaller societies are seeing increasing interest in God and in spiritual life. During the latest, observed period alone, membership in these churches rose more than by a factor of seven. Table 2 outlines developments in the number of believers in various denominations from 1991 to 2001, their share in the total population of Czechia and the date of their registration.

Tab. 2 The structure of religious denominations in Czechia in 1991 and 2001

\begin{tabular}{|c|c|c|c|c|c|c|c|}
\hline & 1991 & & 2001 & & Change & Change & Date of regis- \\
\hline & total & $\%$ & total & $\%$ & 91/01 (no.) & 91/01 (\%) & tration \\
\hline Greek Catholic Church & 7,030 & 0.1 & 7,675 & 0.1 & 645 & 9.2 & $\begin{array}{c}\text { Recognized } \\
\text { from A-H } \\
\text { (revoked } \\
1958-1960)\end{array}$ \\
\hline $\begin{array}{l}\text { Roman Catholic } \\
\text { Church }\end{array}$ & $4,021,385$ & 39.0 & $2,740,780$ & 26.8 & $-1,280,605$ & -31.8 & $\begin{array}{l}\text { Recognized } \\
\text { from A-H }\end{array}$ \\
\hline $\begin{array}{l}\text { Evangelic Church of } \\
\text { Czech Brethren }\end{array}$ & 203,996 & 2.0 & 117,212 & 1.1 & $-86,784$ & -42.5 & $\begin{array}{l}\text { Recognized } \\
\text { from A-H }\end{array}$ \\
\hline $\begin{array}{l}\text { Evangelic Church } \\
\text { Augsburg Confession } \\
\text { in the Czech Rep. }\end{array}$ & - & - & 14,885 & 0.1 & - & - & $\begin{array}{l}\text { Recognized } \\
\text { from A-H }\end{array}$ \\
\hline $\begin{array}{l}\text { Federation of Jewish } \\
\text { Communities in the } \\
\text { Czech Republic }\end{array}$ & 1,292 & 0.0 & 1,515 & 0.0 & 223 & 17.3 & $\begin{array}{l}\text { Recognized } \\
\text { from A-H }\end{array}$ \\
\hline Moravian Church & 2,269 & 0.0 & 3,426 & 0.0 & 1,157 & 51.0 & $\begin{array}{l}\text { Recognized } \\
\text { from A-H }\end{array}$ \\
\hline $\begin{array}{l}\text { Orthodox Church in the } \\
\text { Czech Lands }\end{array}$ & 19,354 & 0.2 & 22,968 & 0.2 & 3,614 & 18.7 & $\begin{array}{l}\text { Recognized } \\
\text { from A-H }\end{array}$ \\
\hline $\begin{array}{l}\text { Evangelic Silesian } \\
\text { Church }\end{array}$ & 33,130 & 0.3 & 14,020 & 0.1 & $-19,110$ & -57.7 & $\begin{array}{l}\text { Recognized } \\
\text { from A-H }\end{array}$ \\
\hline $\begin{array}{l}\text { Old Catholic Church in } \\
\text { the Czech Rep. }\end{array}$ & 2,725 & 0.0 & 1,605 & 0.0 & $-1,120$ & -41.1 & $\begin{array}{l}\text { Recognized } \\
\text { from A-H }\end{array}$ \\
\hline $\begin{array}{l}\text { Czechoslovak Hussite } \\
\text { Church }\end{array}$ & 178,036 & 1.7 & 99,103 & 1.0 & $-78,933$ & -44.3 & 1920 \\
\hline $\begin{array}{l}\text { Religious Society of } \\
\text { Czech Unitarians }\end{array}$ & 365 & 0.0 & 302 & 0.0 & -63 & -17.3 & 1930 \\
\hline Czech Baptist Union & 2,544 & 0.0 & 3,622 & 0.0 & 1,078 & 42.4 & 1951 \\
\hline $\begin{array}{l}\text { Brethren Evangelical } \\
\text { Free Church }\end{array}$ & 2,759 & 0.0 & 9,931 & 0.1 & 7,172 & 260.0 & 1951 \\
\hline $\begin{array}{l}\text { Seventh-day Adventist } \\
\text { Church }\end{array}$ & 7,674 & 0.1 & 9,757 & 0.1 & 2,083 & 27.1 & $\begin{array}{c}1951 \\
\text { (revoked } \\
1952-1956) \\
\end{array}$ \\
\hline $\begin{array}{l}\text { United Methodist } \\
\text { Church }\end{array}$ & 2,855 & 0.0 & 2,694 & 0.0 & -161 & -5.6 & 1951 \\
\hline
\end{tabular}




\begin{tabular}{|c|c|c|c|c|c|c|c|}
\hline & 1991 & & 2001 & & Change & Change & Date of regis- \\
\hline & total & $\%$ & total & $\%$ & 91/01 (no.) & 91/01 (\%) & tration \\
\hline $\begin{array}{l}\text { Evangelical Free } \\
\text { Church }\end{array}$ & 3,017 & 0.0 & 6,927 & 0.1 & 3,910 & 129.6 & 1956 \\
\hline $\begin{array}{l}\text { New Apostolic Church } \\
\text { in the Czech Rep. }\end{array}$ & 427 & 0.0 & 449 & 0.0 & 22 & 5.2 & 1956 \\
\hline $\begin{array}{l}\text { Apostolic Church } \\
\text { (Pentecostal) }\end{array}$ & 1,485 & 0.0 & 4,565 & 0.0 & 3,080 & 207.4 & 1989 \\
\hline $\begin{array}{l}\text { Church of Jesus Christ } \\
\text { of Latter-day Saints } \\
\text { (Mormons) }\end{array}$ & 549 & 0.0 & 1,366 & 0.0 & 817 & 148.8 & 1990 \\
\hline Jehovah's Witnesses & 14,575 & 0.1 & 23,162 & 0.2 & 8,587 & 58.9 & 1993 \\
\hline $\begin{array}{l}\text { Lutheran Evangelical } \\
\text { Church - Augsburg } \\
\text { Confession in the } \\
\text { Czech Rep. }\end{array}$ & - & - & 5,412 & 0.1 & - & - & 1995 \\
\hline Hinduism* & - & - & 767 & 0.0 & - & - & 2002 \\
\hline $\begin{array}{l}\text { Hare Krishna } \\
\text { Movement }\end{array}$ & - & - & 294 & 0.0 & - & - & 2002 \\
\hline $\begin{array}{l}\text { Christian Fellowship } \\
\text { Church }\end{array}$ & - & - & 4,012 & 0.0 & - & - & 2002 \\
\hline $\begin{array}{l}\text { The Christian } \\
\text { Community }\end{array}$ & - & - & - & - & - & - & 2002 \\
\hline Islam** & 495 & 0.0 & 3,699 & 0.0 & 3,204 & 647.3 & 2004 \\
\hline Buddhism*** & - & - & 6,817 & 0.1 & - & - & 2007 \\
\hline $\begin{array}{l}\text { Church of the Living } \\
\text { God }\end{array}$ & - & - & - & - & - & - & 2007 \\
\hline $\begin{array}{l}\text { Vishwa Nirmala } \\
\text { Dharma }\end{array}$ & - & - & - & - & - & - & 2007 \\
\hline $\begin{array}{l}\text { Russian Orthodox } \\
\text { Church, under the } \\
\text { Moscow Patriarch and } \\
\text { all Russia in the Czech } \\
\text { Rep. }\end{array}$ & - & - & - & - & - & - & 2007 \\
\hline Church of God & - & - & - & - & - & - & 2009 \\
\hline Anglican Church & - & - & 201 & 0.0 & - & - & not registr. \\
\hline $\begin{array}{l}\text { Unification Church } \\
\text { (Moonies) }\end{array}$ & - & - & 43 & 0.0 & - & - & not registr. \\
\hline Church of Scientology & - & - & 110 & 0.0 & - & - & not registr. \\
\hline Other & 17,772 & 0.2 & 180,769 & 1.8 & 162,997 & 917.2 & $x$ \\
\hline Believers & $4,523,734$ & 43.9 & $3,288,088$ & 32.1 & $-1,235,646$ & -27.3 & $x$ \\
\hline Non-denominationalists & $4,112,864$ & 39.9 & $6,039,991$ & 59.0 & $1,927,127$ & 46.9 & $x$ \\
\hline Not identified & $1,665,617$ & 16.2 & 901,981 & 8.8 & $-763,636$ & -45.8 & $x$ \\
\hline Total population & $10,302,215$ & 100.0 & $10,230,060$ & 100 & $-72,155$ & -0.7 & $x$ \\
\hline
\end{tabular}

Source of data: CZSO 2008, Ministry of Culture of the Czech Republic 2009.

Note: A-H = Austro-Hungary

* Czech Hindu Religious Society

** Centre of Muslim Communities

*** Diamond Way Buddhism in the Karma Kagyu lineage 
As written above, in 2001, as opposed to 1991, an overall decline in the population of believers was recorded. This decline primarily impacted the traditional and, in Czechia, the most well-represented churches: the Roman Catholic Church (a decline of 1.28 million people $=-31.8 \%$ of the 1991 value), the Evangelic Church of Czech Brethren (a decline of 86.8 thousand people $=-42.5 \%$ of the 1991 value) and the Czechoslovak Hussite Church (a decline of 78.9 thousand $=-44.3 \%$ of the 1991 value). In contrast, during the same observed period, smaller Christian societies, such as the Brethren Evangelical Free Church, the Evangelical Free Church, saw significant membership growth. The Religious Society of Jehovah's Witnesses, which is not normally considered a Christian church, also recorded significant growth by nearly $60 \%$ to approximately 23 thousand in 2001 .

The expansion of new religions in Czechia began after the fall of the communist regime in 1989. These so-called new religions are, according to Partridge (2004), for the most part modifications of older religions, which are presenting themselves in a new situation to a new audience. The newness of a religion can also arise from the establishment of its organization in a certain area. The development of new churches is fed by increases in migration. Newly arriving residents bring their faith with them. The increase in residents claiming membership in the Orthodox Church, between 1991 and 2001, caused by the migration of people, primarily from Ukraine and Russia, into Czechia, serves as an example (Havlíček 2007). Change in the climate of a society is another reason behind the plurality of religions. Such a change can result in a desire to experiment, explore new ideas (Buddhism, Hinduism) as well as the possibility to choose freely. This trend regarding the strengthening of the position of new religious movements is reflected both in the diversification of the Czech religious scene as well as in the spatial distribution of religious communities and has resulted in changes in the religious landscape (Havlíček, Hupková 2008). The role of occult or esoteric expressions (belief in horoscopes, astrology, talismans, etc.) is also increasing significantly in Czech society (Hamplová 2000, Nešpor 2004).

\section{Changes in the spatial distribution of believers}

Previous studies of Czechia's religious landscape (e.g. Daněk, Štěpánek 1992, Havlíček, Hupková 2008) have shown significant inequality in terms of the spatial distribution of believers.

Which of Czechia's districts, therefore, show a high level of heterogeneity and which districts saw the largest decreases in heterogeneity between 1991 and 2001 ? Are differences in the structure of religiosity in Czechia's various districts becoming more pronounced? Are the adherents of the various, individual churches evenly distributed through Czechia's districts? This article seeks to answer these and other questions.

The appearance of new groups on the Czech religious scene, along with small increases in the number of people claiming membership in churches and reli- 


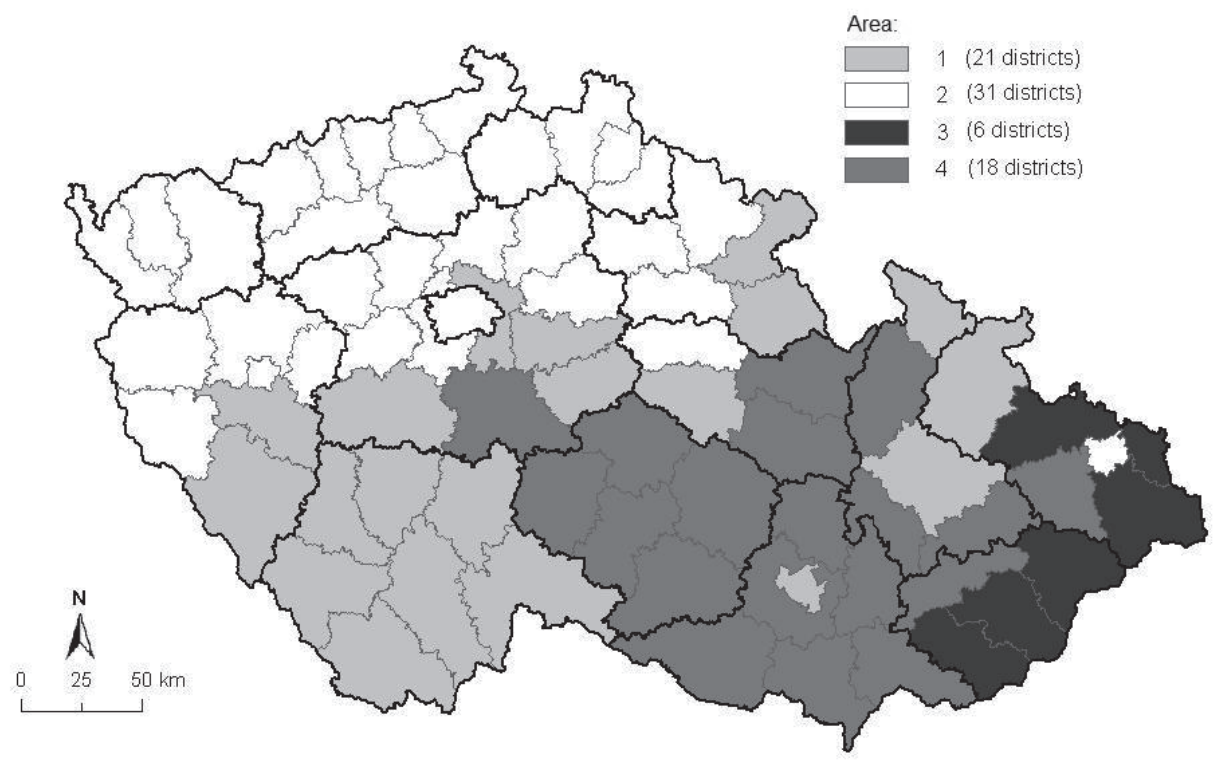

Fig. 2 Typology of areas in terms of changes in the portion of Roman Catholic believers Source: authors' creation.

gious societies, which were already operating in Czechia but which, in terms of number of members and overall influence, did not rank among the significant and influential denominations, represent interesting current trends. As a result of these trends, the homogeneity in Czechia's religious structure is decreasing. At the same time, believers are becoming increasingly territorially concentrated. The $\mathrm{H}$ indicator of territorial inequality ${ }^{1}$ increased slightly between 1991 and 2001 from $78.8 \%$ to $81 \%$.

The increase in the spatial concentration of believers is connected with a general increase in the concentration of residents into cities (Hampl, Gardavský, Kühnl 1987) and their hinterlands (Hampl 2007), on the one hand, while it is also due to the consequences of a general decline in believers, on the other. We shall attempt to demonstrate this development with the example of the Roman Catholic Church, which is the dominant religious society in Czechia and which, as a result, best reflects general trends in Czech society. Their "core" areas (territories with a highly above-average portion of Roman Catholic believers) did not see such a large decrease as did areas, in which the portions of their adherents had been average or below average for an extended period of time. Consequently, the level of concentration became still greater. Table 3 and Figure 2 provide a more detailed view (at the district level) of

1 The $\mathrm{H}$ indicator of territorial inequality - in calculating this value, the relative frequencies of numbers of believers are accumulated in relation to the area of the territorial unit in question. The indicator answers the question - on what portion of the area is $50 \%$ of the observed phenomenon concentrated? 
changes in the distribution of adherents to the Roman Catholic Church. These changes, the same as changes in any other church or religious society, could have been caused by a change in the religious denomination / or lack of a denomination claimed between the observed years, as well as death, migration or, possibly, by a change in the methods for collecting information on the phenomenon in question. The degree to which these processes contributed to the overall decline can only be guessed at. The insufficient availability of data (e.g. the religious denomination of a newly deceased person is not ascertained) creates a barrier for making such discoveries. With certainty, however, the mere influence of methods used in the collection of data can be eliminated as a possible cause, because the questions regarding a religious declaration were identical in principle in the 1991 and 2001 censuses.

The areas highlighted in figure 2 were determined on the basis of an indicator describing the change in the portion of Roman Catholic believers (as a \%) and an index of change 2001/1991 (as a \%). They were also evaluated on the basis of the average for all of Czechia. Average values for these indicators for the various territories as well as for Czechia as a whole are listed in Table 3, including portions of believers in the Roman Catholic Church.

Tab. 3 Summary of basic indicators for the areas (groups of districts in Czechia) with varying dynamics in terms of the decrease in Roman Catholic believers between 1991 and 2001

\begin{tabular}{|l|c|c|c|c|}
\hline \multirow{2}{*}{ Area } & \multicolumn{2}{|c|}{$\begin{array}{c}\text { Share of Roman Catholic believers in the } \\
\text { total population (\%) }\end{array}$} & $\begin{array}{c}\text { Change in the share } \\
\text { of Roman Catholic } \\
\text { believers (\%) }\end{array}$ & $\begin{array}{c}\text { Index of change } \\
\mathbf{2 0 0 1 / 1 9 9 1}(\%)\end{array}$ \\
\cline { 2 - 3 } & $\mathbf{1 9 9 1}$ & $\mathbf{2 0 0 1}$ & -14.9 & 35.2 \\
\hline 1 & 42.8 & 27.9 & -10.1 & 39.7 \\
\hline 2 & 26.1 & 15.9 & -11.3 & 20.8 \\
\hline 3 & 55.4 & 44.2 & -14.9 & 27.8 \\
\hline 4 & 53.1 & 38.2 & -12.2 & 32.7 \\
\hline Czechia & 39.0 & 26.8 & & \\
\hline
\end{tabular}

Source: authors' creation, source of data: CZSO 1991, CZSO 2001, CZSO 2008.

Note: index of change $=100-\left[\left(\mathrm{a}_{2001} / \mathrm{a}_{1991}\right) \cdot 100\right]$, change in share $=\mathrm{a}_{2001}-\mathrm{a}_{1991}$, where " $\mathrm{a}$ " is the number of believers

The area (group of districts), where changes manifested themselves least (both absolutely and relatively below average change), is made up of those territories with a high share of Roman Catholic believers. Primarily this consists of districts along the border with Slovakia (Uherské Hradiště, Hodonín, Zlín, Vsetín, Frýdek-Místek) and Opava and Karviná districts (area 3), which also shows the lowest dynamic of change in contrast with the other regions (Table 3). On the other hand, regions with the largest decreases comprise area 1 (mainly southern and south-western Bohemia, eastern Silesia), meaning territories, where shares of Roman Catholic believers are average or below average values. This region is characterized by a higher level of rural settlement, primarily small municipalities and settlements as well as a larger share of residents older than 65 . If we were to consider only the in- 
dex of change, a relative expression of change, as a criterion, the districts in area 2 (northern and north-eastern Bohemia, partially central and eastern Bohemia) would also be classified as territories that experienced large changes. These are primarily districts with a higher level of urbanization and industrialization, which show longterm, below-average levels of religiosity. With these areas, however, we must point out the possibility of skewed or distorted results. The disparate initial situation of the districts, in terms of the share of Roman Catholic believers, provides a reason to give special attention to their evaluation. In this section of Czechia, shares of Roman Catholic believers were measured at below-average levels in 1991 and 2001. Changes in such areas, with low initial values of a given phenomenon, can stand out much more in relative expressions, even though when viewed as absolute change they might not be so significant. The final type of changes comprises area 4 , which exhibits a high level of heterogeneity based on the various characteristics. This is primarily the area covering the Vysočina and South Moravia Regions, which are characterized by a long-term, high level of religiosity and also by a large share of Roman Catholic believers.

Other traditional churches (primarily the Evangelic Church of Czech Brethren and the Czechoslovak Hussite Church) were naturally also subject to a decline in membership between 1991 and 2001; however, in contrast to the Roman Catholic Church, the areas where these churches lost the most members were the same areas where they had the largest shares of their adherents. This was manifested in the $\mathrm{H}$ indicator of territorial inequality, the value of which changed only slightly for these churches (see Table 4) and, in the case of the Czechoslovak Church, there was even a tendency towards de-concentration.

Tab. 4 The level of concentration of adherents to selected denominations within Czechia (at the district level, as a $\%)$

\begin{tabular}{|l|c|c|}
\hline \multirow{2}{*}{} & \multicolumn{2}{|c|}{ The H indicator of territorial inequality (\%) } \\
\cline { 2 - 3 } & $\mathbf{1 9 9 1}$ & $\mathbf{2 0 0 1}$ \\
\hline Total believers & $\mathbf{7 8 . 8}$ & 81.0 \\
\hline Roman Catholic Church & 79.9 & 81.0 \\
\hline Orthodox Church in the Czech lands & 89.7 & 91.5 \\
\hline Evangelic Church of Czech Brethren & 87.0 & 88.2 \\
\hline Evangelic Silesian Church & 97.9 & 98.4 \\
\hline Czechoslovak Hussite Church & 90.1 & 89.4 \\
\hline Greek Catholic Church & 91.5 & 89.5 \\
\hline Moravian Church & 95.1 & 92.4 \\
\hline Religious Society of Jehovah's Witnesses & 93.3 & 90.2 \\
\hline Seventh-day Adventist Church & 93.8 & 90.0 \\
\hline Brethren Assemblies & 94.6 & 88.1 \\
\hline Other & 91.8 & 86.5 \\
\hline
\end{tabular}

Source: authors' creation, source of data: CZSO 1991, CZSO 2001, CZSO 2008. 
Table 4 also shows the $\mathrm{H}$ indicator of territorial inequality for a number of additional denominations. Their selection was influenced primarily by the volume of their membership $(0.1 \%<$ share in the total population), and also by whether a given church had a corresponding equivalent in both censuses (1991 and 2001). Two opposing trends became evident in the research. On the one hand, concentration tendencies are underway for the larger churches (e.g. the Roman Catholic Church, Evangelic Church of Czech Brethren, Orthodox Church), while on the other hand, with all of the smaller churches and religious societies in Czechia (e.g. Brethren Evangelical Free Church, Evangelical Free Church, etc.), a trend toward de-concentration can be observed. The individual adherents and congregations of these churches are increasingly spatially distributed over a larger area of Czechia, primarily due to both absolute and relative growth in members. The expansion of these churches subsequently plays a role in the increasing regional heterogeneity of Czechia's religious landscape.

Exceptions to this include the Evangelic Silesian Church in the Czech Republic, the name of which attests to the fact that its activities are tied in to a certain territory - Silesia.

\section{A spatial view of the growth of heterogeneity in religious adherence}

Values from an index of homogeneity ${ }^{2}$, from 1991 and 2001, document an increase in the heterogeneity of religious adherence in Czechia. In 2001, this index showed a value of $83.7 \%$, which was $5.4 \%$ lower than in 1991 . When we examine values of this index of homogeneity at the district level, we find that homogeneity declined, during the observed period, in all of Czechia's districts. The index of homogeneity fell by anywhere from 3.16\% (Hodonín) to $11.78 \%$ (Prague). Figure 2 shows the index of homogeneity in 2001. Districts in southern Moravia (Uherské Hradiště, Třebíč, Hodonín, Znojmo) achieve the highest levels of homogeneity, in terms of religious adherence (see Fig. 3). These are traditional religious areas where Christianity holds a dominant position. For local residents, religion is a part of everyday life; the influence of the church in cultural and societal life in these areas is also significant. The most religiously heterogeneous areas of Czechia include the Liberec and Ústí nad Labem Regions, the eastern part of the MoravianSilesian Region (Frýdek-Místek and Karviná Districts), certain districts in the Central Bohemian Region (Nymburk, Praha-západ and Rakovník) and Prague.

\footnotetext{
Index of homogeneity

$H=\sqrt{\frac{h_{1}^{2}+h_{2}^{2}+h_{3}^{2}+h_{4}^{2}+\ldots}{h^{2}}} \cdot 100=\sqrt{p_{1}^{2}+p_{2}^{2}+p_{3}^{2}+p_{4}^{2}+\ldots}$

Where $h$ is the number of believing residents in a given district

If this index equals $100 \%$, it means that only adherents to one church live in the observed territorial unit. With a growing number of churches and religious denominations or with any increase in their relative share, the value of the index of homogeneity falls. The index of homogeneity is used primarily in evaluating the homogeneity of a territory in terms of nationality.
} 


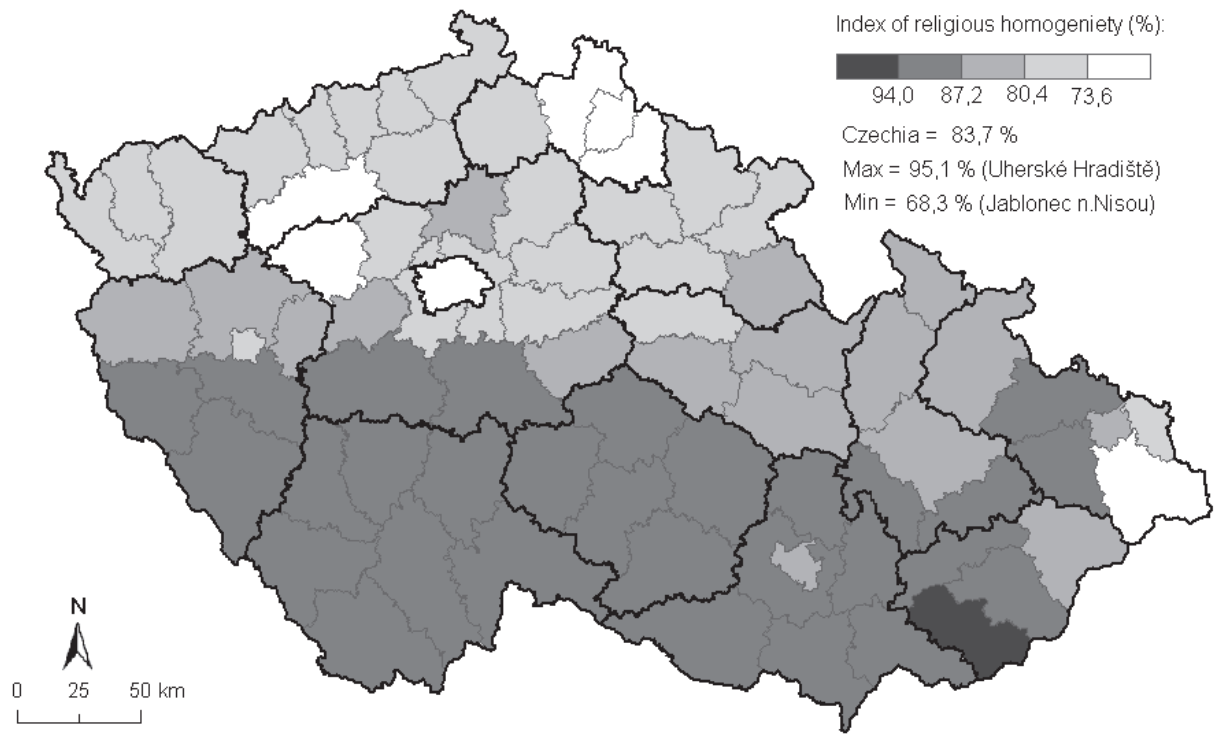

Fig. 3 Index of religious homogeneity in Czechia's districts in 2001 Source: authors' creation, source of data: CZSO 1991, CZSO 2001.

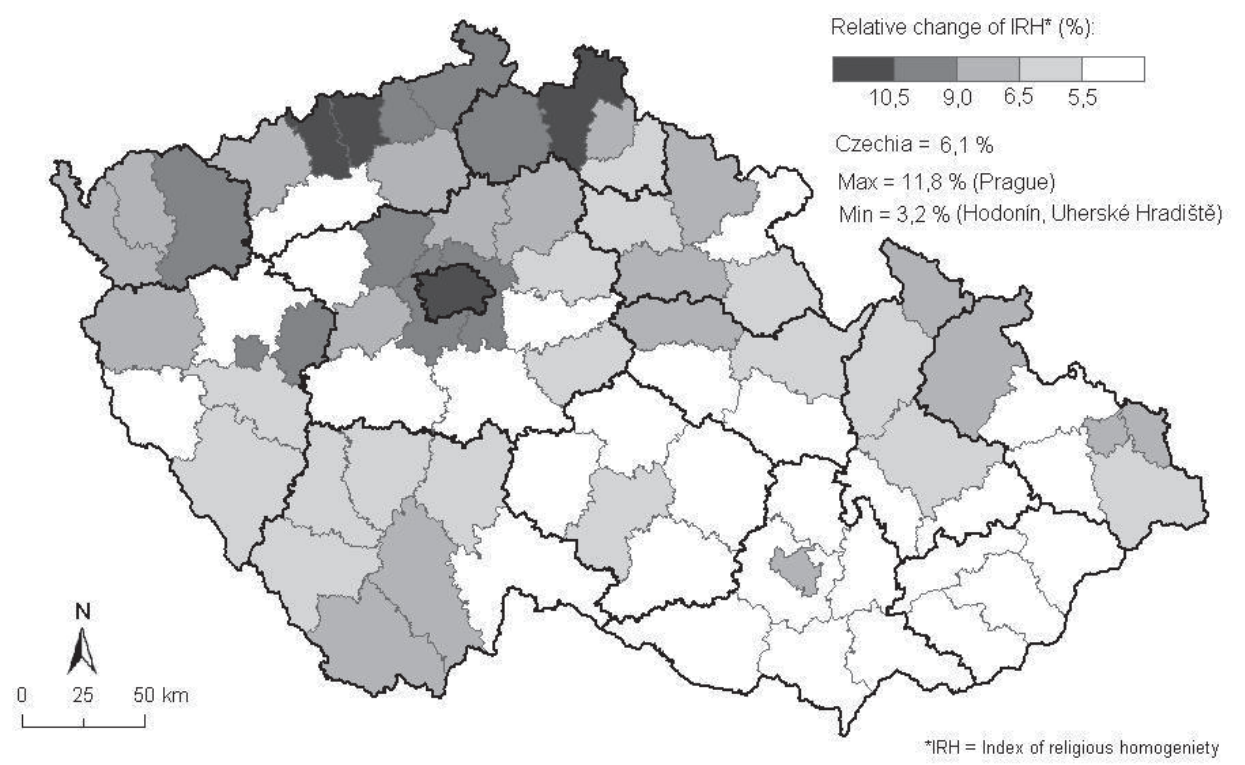

Fig. 4 Changes to the index of religious homogeneity in Czechia's districts between 1991 and 2001 Source: authors' creation, source of data: CZSO 1991, CZSO 2001. 


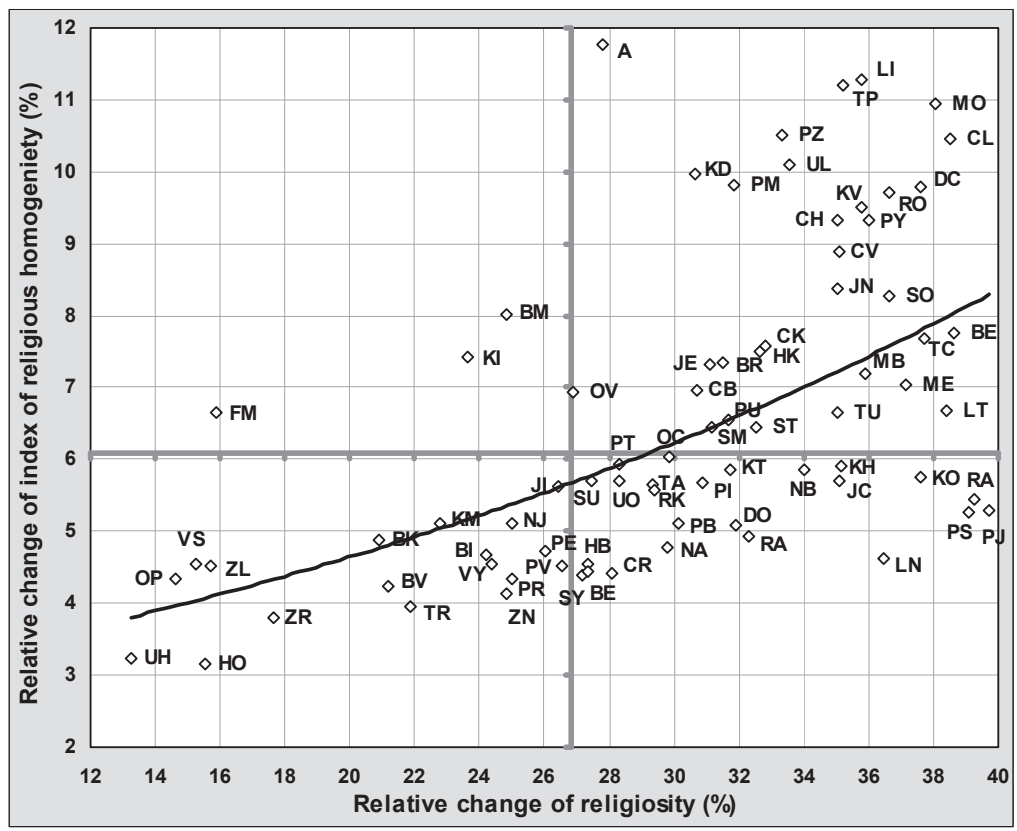

Fig. 5 Relation between the index of homogeneity and change in the level of religiosity between 1991 and 2001

Source: authors' creation, source of data: CZSO 1991, CZSO 2001.

A negative statistical correlation can be detected between the value of the index of homogeneity and the development of homogeneity during the observed period (correlation: -0.66). Districts, which show the highest level of homogeneity, exhibit only a small decline in homogeneity; while districts with the lowest levels of homogeneity exhibit more significant decreases in the index of homogeneity. This is an expression of the increasing differences between the districts in Czechia. In this way, the regional differentiation of Czechia's religious landscape is becoming more pronounced.

This research on religious heterogeneity in Czechia also included the dependent relationship of the index of homogeneity on change in the level of religiosity between 1991 and 2001 at the district level (Fig. 5). The results demonstrate a positive correlation between these two variables with a value of 0.56 and, with certain degree of caution, it is possible to state the conclusion that increasing secularization in an area also leads to the increasing heterogeneity of the religious landscape of the area. In other words, districts showing low, or lower than average, change in the level of religiosity (Uherské Hradiště, Vsetín, Hodonín etc.) also exhibit low, or lower than average, relative change in the index of religious homogeneity and vice versa. The only exception to this is the capital city of Prague, which as a significant European metropolitan area exhibits the highest increase in religious heterogeneity, 
primarily due to the immigration of foreigners with resultant increases in new religious directions, as well as a merely average decline in religiosity or in the growth of secularization. In order to further generalize the above results, additional research encompassing a greater period of time as well as more detailed research of model regions will be necessary.

\section{Conclusion}

This submitted study has attempted to generalize changes in the geographic distribution of religious heterogeneity or homogeneity in Czechia during the transformation period from 1991 to 2001 .

The hypothesis stated in the introduction regarding the role of increases in religious heterogeneity as a factor that can subsequently contribute to moderating processes of secularization has, for the time being, not been confirmed. The only exception is the capital city of Prague, where such moderation actually occurred, in all other cases growth in secularization in an area also led to growth in the religious heterogeneity of the landscape and vice versa.

Areas with a higher degree of religious homogeneity exhibit smaller declines in the level of homogeneity when compared with regions with a higher level of religious heterogeneity, which also exhibit greater declines in homogeneity or greater increases in spatial religious heterogeneity. In this way, the regional differentiation of Czechia's religious landscape is becoming more pronounced.

An increase in heterogeneity at the national level in Czechia was confirmed thanks in part to an increase in registered churches after 1989, after which time 13 new churches or religious societies were registered.

Areas with higher religiosity, therefore, generally are regions with a higher degree of homogeneity and vice versa. The Ostrava agglomeration presents the only exception to this trend.

Generally speaking, believers are becoming more concentrated within Czechia, primarily due to developments in the Roman Catholic Church as the largest religious community in Czechia, which support this tendency. In contrast, the expansion of smaller, primarily evangelical churches (Brethren Evangelical Free Church, Adventists, Evangelical Free Church, etc.) are causing increases in the regional heterogeneity of Czechia's religious landscape.

\section{Acknowledgements}

This paper is the result of research findings sponsored by a financial grant, project GA AV: No. IAA701110701, "Differentiation of changes of religious landscape in Czechia during the period of transformation". The authors would like to thank the sponsors for their financial support. 


\section{References}

CZSO (2008a): www.czso.cz (25. 9. 2009).

CZSO (2008b), Veřejná diskuze o návrhu zákona SLDB 2011 - Souhrnné vyhodnocení: www.czso.cz (1. 9. 2009).

DANĚK, P., ŠTĚPÁNEK, V. (1992): Územní diferenciace náboženského vyznání obyvatel českých zemí 1930-1991. (Territorial Diffentiation of Religions in the Czech Lands 1930-1991). In: Sborník ČGS, 97, Nr. 3, s. 129-145.

HAMPL, M., GARDAVSKÝ, V., KÜHNL, K. (1987): Regionální struktura a vývoj systému osídlení ČR. Praha: UK, 255 s.: tab. +4 príl.

HAMPL, M. (2007): Regionální diferenciace současného socioekonomického vývoje v ČR. Sociologický časopis, 43, č. 5, s. 889-910.

HAMPLOVÁ, D. (2000): Šetření ISSP 1998 - Náboženství. (Survey ISSP 1998 - Religion). In: Sociologický časopis, XXXVI, 4, s. 431-440.

HAVLÍČEK, T. (2005): Czechia: secularisation of the religious landscape. In: Knippenberg, H. (ed.): The changing religious landscape of Europe. Het Spinhuis, Amsterdam, s. 189-200.

HAVLÍČ́EK, T. (2007): Pravoslaví v Česku. (Orthodoxy in Czechia). In: Geografické rozhledy, 16, 5, s. $24-25$.

HAVLÍČEK, T., HUPKOVÁ, M. (2008): Religious landscape in Czechia: new structures and trends. Geografie-Sborník ČGS, roč. 113, č. 2, 302-319.

HENKEL, R., KNIPPENBERG, H. (2005): Secularisation and the rise of religious pluralism. In: Knippenberg, H. (ed.), The changing religious landscape of Europe. Het Spinhuis, Amsterdam, pp. 1-13.

KNIPPENBERG, H. (ed.) (2005): The changing religious landscape of Europe. Het Spinhuis, Amsterdam, $218 \mathrm{~s}$.

LUŽNÝ, D., NAVRÁTILOVÁ, J. (2001): Religion and Secularisation in the Czech Republic. Czech Soziological Review, Vol. 9, No. 1, s. 85-98.

MINISTERSTVO KULTURY ČR (2009): www.mkcr.cz (25. 9. 2009).

NEŠPOR, Z. R. (ed.) (2004): Jaká víra? Současná česká religiozita/spiritualita v pohledu kvalitativní sociologie náboženství. Sociologické studie, 04:05, Sociologický ústav AV ČR, Praha, 115 s.

PARK, CH. C. (1994): Sacred worlds. An Introduction to Geography and Religion. Routledge, London, $332 \mathrm{s.}$

PARTRIDGE, CH. (2004): Encyclopedia of new religions: New religious movements, sects and alternative spiritualities. Lion Hudson Plc, Oxford, $446 \mathrm{~s}$.

SOBOTKA, T., ADIGÜZEL, F. (2002): Religiosity and spatial demographic differences in the Netherlands. Research paper. Graduate School/Research Institute, Systems, Organisations and Management (SOM), $23 \mathrm{~s}$.

WUNDER, E. (2005): Religion in der postfonfessionellen Gesellschaft. Ein Beitrag zur sozialwissenschaftlichen Theorieentwicklung in der Religionsgeographie. In: Sozialgeographische Bibliothek, Band 5, Franz Steiner Verlag, Stuttgart, 366 s.

\section{Resumé \\ Změny geografického rozmístění náboženské heterogenity v Česku v období transformace}

Předložená studie se pokusila zobecnit změny geografického rozmístění náboženské heterogenity, resp. homogenity v Česku v období transformace za roky 1991 až 2001.

Nárůstu náboženské heterogenity jako faktoru, který pak může přispět ke zmírnění procesu sekularizace se zatím nepotvrdil. Výjimkou je pouze hlavní město Praha, kde $\mathrm{k}$ tomuto zmírnění došlo, ale jinak nárůst sekularizace v území vede i k nárůstu heterogenity náboženské krajiny a naopak.

Území s vyšší mírou náboženské homogenity zaznamenávají nižší pokles míry homogenity oproti regionům s vyšší mírou religiózní heterogenity, které pak vykazují i vyšší pokles homogenity, resp. vyšší nárůst náboženské heterogenity v prostoru. Dochází tak k nárůstu regionální diferenciace religiózní krajiny v Česku. 
Nárůst heterogenity na úrovni Česka byl potvrzen i díky nárůstu registrovaných církví po roce 1989, kdy bylo zaregistrováno 13 nových církví či náboženských společností.

Oblasti s vyšší religiozitou pak představují většinou regiony i s vyšší mírou homogenity a naopak. Výjimku zde představuje pouze ostravská aglomerace.

V Česku obecně dochází ke koncentrickým tendencím věrících a to především díky Římskokatolické církvi jako největší náboženské komunitě v Česku, která tento trend naplňuje. Naopak expanze menších především evangelikálních církví (Církev bratrská, adventisté, Křest’anské sbory atd.) pak způsobuje nárůst regionální heterogenity religiózní krajiny v Česku.

Tomáš Havlíček

Charles University in Prague

Department of Social Geography and Regional Development

Faculty of Science

Albertov 6

12843 Prague 2

Czech Republic

e-mail: tomhav@natur.cuni.cz 